Techniques \& Culture

\title{
Langages de ficelle. Au fil d'une enquête dans le Chaco argentin
}

José Braunstein

\section{(2) OpenEdition}

12 Journals

Édition électronique

URL : https://journals.openedition.org/tc/489

DOI : $10.4000 /$ tc.489

ISSN : 1952-420X

Éditeur

Éditions de l'EHESS

\section{Édition imprimée}

Date de publication : 1 octobre 1996

ISSN : 0248-6016

\section{Référence électronique}

José Braunstein, «Langages de ficelle. Au fil d'une enquête dans le Chaco argentin », Techniques \& Culture [En ligne], 27 | 1996, mis en ligne le 28 octobre 2005, consulté le 29 septembre 2022. URL : http://journals.openedition.org/tc/489; DOI : https://doi.org/10.4000/tc.489

Ce document a été généré automatiquement le 29 septembre 2022.

Tous droits réservés 


\section{Langages de ficelle. Au fil d'une enquête dans le Chaco argentin}

José Braunstein 